\title{
Effects of the whole seed and a protein isolate of faba bean (Vicia faba) on the cholesterol metabolism of hypercholesterolaemic rats
}

\author{
M. Teresa Macarulla ${ }^{1}$, César Medina ${ }^{1}$, M. Aránzazu De Diego ${ }^{1}$, M. Chávarri ${ }^{1}$, M. Ángeles Zulet ${ }^{2}$, \\ J. Alfredo Martínez ${ }^{2}$, Catherine Nöel-Suberville ${ }^{3}$, Paul Higueret ${ }^{3}$ and María P. Portillo ${ }^{1}$ \\ ${ }^{1}$ Department of Nutrition and Food Science, University of País Vasco, Paseo de la Universidad 7, 01006 Vitoria, Spain \\ ${ }^{2}$ Department of Physiology and Nutrition, University of Navarra, Irunlarrea $s / n, 31008$ Pamplona, Spain \\ ${ }^{3}$ Laboratory of Nutrition, University of Bordeaux I, Avenue des Facultés, 33405 Talence, France
}

(Received 11 February 2000 - Revised 11 December 2000 - Accepted 21 December 2000)

\begin{abstract}
The aim of the present work was to analyse the hypocholesterolaemic efficiency of a Vicia fabaprotein isolate in relation to the intact legume. In addition, the mechanisms underlying the effects of this isolate were investigated. Hypercholesterolaemic rats were divided into three groups $(n 10 \times 3)$ and fed high-fat diets rich in cholesterol-containing casein, whole seeds of Vicia faba or the protein isolate of faba beans as protein source, for 2 weeks ad libitum. The protein isolate was prepared by isoelectric precipitation and spray dried. Analyses of serum, liver and faeces, as well as of the activity of hepatic 3-hydroxy-3-methylglutaryl (HMG)-CoA reductase, were assessed by enzymatic methods. The rats fed on Vicia faba diets showed significantly lower body weights and energy intakes than rats fed on casein diets. The wholeseed diet induced a significant reduction in plasma triacylglycerol. Feeding rats on diets containing faba bean seeds, or the protein isolate, induced a significant decrease in plasma (LDL+VLDL)-cholesterol but not in HDL-cholesterol. Hepatic cholesterol and triacylglycerol were also reduced. The hypocholesterolaemic effects of Vicia faba were not the result of a reduction in cholesterol synthesis as assessed from HMG-CoA reductase activity, but the result of an increase in steroid faecal excretion. The faba bean-protein isolate obtained under our experimental conditions was useful in improving the metabolic alterations induced by feeding with a hypercholesterolaemic diet compared with casein. The effectiveness of the whole seeds was higher than that of the protein isolate.
\end{abstract}

Faba bean: Protein isolate: Hypercholesterolaemia

Cholesterol is an important constituent of living tissues by virtue of its dual role both as a structural component of biological membranes, and as a precursor of cholecalciferol, steroid hormones and bile acids. Cholesterol also acts as a risk factor for adverse conditions such as cardiovascular diseases and cholelithiasis. Several studies have demonstrated that lowering LDL-cholesterol diminishes both cardiovascular and overall mortality (Dwyer, 1995).

It is well known that diet plays an important role in the control of cholesterol homeostasis. In this context, it has been reported that legumes lower serum LDL-cholesterol (Duane, 1997). Although most of the studies have been carried out using soyabean, other legumes such as kidney beans, peas, chickpeas, etc have also shown hypocholesterolaemic properties (Sharma, 1987; Kingman et al. 1993;
Zulet \& Martínez, 1995; Zulet et al. 1999b). Different components such as protein, amino acids and peptides, isoflavones, saponins, phytic acid, fibres, and protease inhibitors have been suggested as being responsible for the hypocholesterolaemic effect of legumes (Potter, 1995; Frühbeck, 1996a,b). Nevertheless, the results remain inconclusive.

In this context, a great many studies have focused on the hypercholesterolaemic effect of legume protein compared with proteins from animal origin, such as casein. It has been demonstrated that the serum cholesterol concentration in rats fed on soyabean protein was significantly lower than that in rats fed casein (Forsythe, 1986; Tanaka \& Sugano, 1989).

With regard to the mechanisms underlying the effects of

\footnotetext{
Abbreviations: C, reference-control group; HC, hypercholesterolaemic diet with casein; HI, hypercholesterolaemic diet with Vicia faba-protein isolate; HMG-CoA, 3-hydroxy-3-methyl-CoA; HS, hypercholesterolaemic diet with Vicia faba seeds.

* Corresponding author: Dr M. Teresa Macarulla, fax + 34945 130756, email knpmaarm@vc.ehu.es
} 
soyabean protein, Nagata et al. (1982) showed that soyabean protein increased faecal cholesterol excretion as a consequence of a reduction of intestinal absorption. In other studies, it has been suggested that soyabean protein increases cholesterol saturation of bile by increasing biliary secretion of cholesterol (Potter, 1995). Moreover, consumption of soyabean protein may be associated with an increased removal of LDL and VLDL by hepatocytes as compared with casein consumption (Khosla et al. 1991).

The aim of the present work was to analyse the hypocholesterolaemic efficiency of a Vicia faba-protein isolate in relation to the intact legume. In addition, the mechanisms underlying the effects of this isolate were investigated.

\section{Materials and methods}

\section{Protein isolate preparation}

Faba bean proteins were isolated from seeds of Vicia faba, obtained from a local supplier, according to the method described by Thompson (1977) and modified by Fernández-Quintela et al. (1997). Briefly, dehulled seeds were ground to obtain a flour with a particle size $<0.7 \mathrm{~mm}$. Aqueous dispersion of this flour $(1: 5, \mathrm{w} / \mathrm{v})$ was adjusted to $\mathrm{pH} 9.0$ with $1 \mathrm{M}-\mathrm{NaOH}$ and then centrifuged $(1000 \mathrm{~g}$ for $20 \mathrm{~min}$, at room temperature). The supernatant fraction was adjusted to $\mathrm{pH} 4.0$ with $1 \mathrm{M}-\mathrm{HCl}$ and centrifuged again. Finally, the protein pellet was resuspended in water $(1: 5, \mathrm{w} /$ v), adjusted to $\mathrm{pH} 7.0$ with $1 \mathrm{M}-\mathrm{NaOH}$, and the final suspension was spray dried as described by Otegui et al. (1997).

\section{Legume seed and protein isolate composition analysis}

For this analysis, the official methods of the Association of Official Analytical Chemists (1997) were used. Water and ash contents were determined gravimetrically, total protein by the Kjeldahl method, fat by diethyl ether extraction in a Soxhlet apparatus, crude fibre by a chemical-gravimetric method, and carbohydrates were extracted by perchloric acid and quantified by the antrona spectrophotometric method. Results are shown in Table 1.

\section{Experimental design}

Male Wistar rats (Charles River, Barcelona, Spain) were used for this experiment. Animals were housed individually and maintained in a temperature $\left(23 \pm 2^{\circ} \mathrm{C}\right)$ and humidity (50\%)-controlled room with $12 \mathrm{~h}$ light-dark cycle, lights on at 08.00 hours, with free access to water and food. Thirty-five rats (195 (SE 5) g) were fed on a high-fat diet rich in saturated fatty acids and cholesterol (HC) ad libitum for 3 weeks, in order to induce a hypercholesterolaemic status (Zulet et al. 1999a). At the end of this period, five rats were killed to check that hypercholesterolaemia was achieved. The remaining thirty rats (278 (SE 2) g) were randomized and assigned to three groups receiving the following diets ad libitum for 2 weeks: one hypercholesterolaemic-control group (HC, $n$ 10) was maintained on the diet HC, another group (HS, $n$ 10) received the high-fat diet
Table 1. Composition of Vicia faba seeds and protein isolate $(\mathrm{g} / \mathrm{kg})^{\star}$ (Mean values of three to five replicates)

\begin{tabular}{lrc}
\hline & Seed & Protein isolate \\
\hline Protein & 252 & 773 \\
Carbohydrates & 465 & 51 \\
Fat & 15 & 32 \\
Fibre & 103 & 55 \\
Ash & 56 & 57 \\
Moisture & 109 & 32 \\
\hline
\end{tabular}

* For details of protein isolation procedure, see p. 608. Analyses were done according to the methods of the Association of Official Analytical Chemists (1997).

rich in cholesterol containing whole seeds of Vicia faba (HS diet), and the third group (HI, $n$ 10) received the highfat diet rich in cholesterol containing the protein isolate of faba beans (HI diet).

An additional reference-control group of rats with a mean body weight of 195 (SE 3) g (C, $n$ 10) was fed on a semi-purified control diet during the 5 weeks of the whole experimental period. The values of the studied variables obtained from this group were used to assess if the changes induced by legume dietary treatments reached the baseline values.

The composition of diets is given in Table 2. According to the results of the seed and protein isolate composition analysis (Table 1), both legume diets (HS and $\mathrm{HI}$ ) were formulated so that each diet provided approximately the same amount of proteins, carbohydrates, lipids, vitamins, minerals, cholesterol and cholic acid as the $\mathrm{HC}$ diet.

Table 2. Composition of experimental diets

\begin{tabular}{|c|c|c|c|c|}
\hline & C & $\mathrm{HC}$ & HS & $\mathrm{HI}$ \\
\hline \multicolumn{5}{|l|}{ Ingredients (g/kg) } \\
\hline Casein* & 200 & 200 & - & - \\
\hline Vicia faba seeds & - & - & 684 & - \\
\hline Vicia faba-protein isolate & - & - & - & 233 \\
\hline L-Methionine & 1 & 1 & 1 & 1 \\
\hline Saccharose & 322 & 479 & - & 446 \\
\hline Wheat starch & 322 & - & - & - \\
\hline Olive oil & 50 & 50 & 50 & 50 \\
\hline Coconut oil & - & 200 & 200 & 200 \\
\hline Cholesterol & - & 10 & 10 & 10 \\
\hline Cholic acid & - & 5 & 5 & 5 \\
\hline Cellulose & 50 & - & - & - \\
\hline Mineral mix $†$ & 45 & 45 & 40 & 45 \\
\hline Vitamin mix† & 10 & 10 & 10 & 10 \\
\hline Choline chloride & 1 & 1 & 1 & 1 \\
\hline \multicolumn{5}{|l|}{ Nutritional composition } \\
\hline Protein $(\mathrm{g} / \mathrm{kg})$ & 181 & 181 & 173 & 181 \\
\hline Fat $(\mathrm{g} / \mathrm{kg})$ & 50 & 250 & 260 & 257 \\
\hline Saturated FA $(\mathrm{g} / 100 \mathrm{~g})$ & $13 \cdot 8$ & $76 \cdot 0$ & 73.6 & 74.2 \\
\hline Monounsaturated FA $(\mathrm{g} / 100 \mathrm{~g})$ & $75 \cdot 2$ & 20.5 & 21.5 & $21 \cdot 2$ \\
\hline Polyunsaturated FA $(\mathrm{g} / 100 \mathrm{~g})$ & $11 \cdot 1$ & 3.5 & $5 \cdot 0$ & 4.6 \\
\hline Carbohydrates (g/kg) & 644 & 479 & 318 & 458 \\
\hline Simple sugars $(\mathrm{g} / \mathrm{kg})$ & 322 & 479 & 62 & 448 \\
\hline Complex carbohydrates (g/kg) & 322 & 0 & 256 & 10 \\
\hline Fibre $(\mathrm{g} / \mathrm{kg})$ & 50 & 0 & 70 & 13 \\
\hline Energy (MJ/kg) & $15 \cdot 7$ & $20 \cdot 4$ & $18 \cdot 0$ & $20 \cdot 4$ \\
\hline
\end{tabular}

C, control diet; HC, hypercholesterolaemic diet with casein; HS, hypercholesterolaemic diet with Vicia faba seeds; HI, hypercholesterolaemic diet with Vicia faba protein isolate; FA, fatty acids.

* $900 \mathrm{~g}$ casein $/ \mathrm{kg}$.

† Formulated according to the American Institute of Nutrition (AIN-93; Reeves et al. 1993). 
Food intake was measured each day during the treatment period. During the last $4 \mathrm{~d}$, the faeces were individually collected and stored at $-80^{\circ} \mathrm{C}$ until analysis. At the end of the experimental period and after an overnight fast, the rats were decapitated. Blood was collected and centrifuged, and the serum was frozen and stored $\left(-80^{\circ} \mathrm{C}\right)$ until analysis of the biochemical variables. The liver and the spleen were excised, weighed and washed in cold saline $(9 \mathrm{~g} \mathrm{NaCl} / \mathrm{l})$ solution, and immediately frozen in liquid $\mathrm{N}_{2}$ and stored at $-80^{\circ} \mathrm{C}$ for subsequent analyses.

\section{Serum analyses}

Serum samples were analysed for total cholesterol, HDLcholesterol and triacylglycol levels in a BM/HITACHI ${ }^{\mathrm{TM}}$ 717 Autoanalyser (Hitachi Instruments Inc. San Jose, CA, USA) by using commercial kits (Triacylglycerol GPO-PAP and Cholestén CHOD-PAP; Boehringer Mannheim GmbH, Mannheim, Germany). The cholesterol-lipoprotein (LDL+VLDL) fraction was separated from the HDL fraction by precipitation with dextran sulfate- $\mathrm{MgCl}_{2}$ (Warnick et al. 1982). The (LDL+VLDL)-cholesterol was calculated by the subtraction of HDL-cholesterol from total cholesterol. The atherogenic index was calculated as the (VLDL+LDL)-cholesterol:HDL-cholesterol ratio.

\section{Analyses of hepatic lipids}

Hepatic lipids were extracted with chloroform-methanol $(2: 1, \mathrm{v} / \mathrm{v})$ using the method of Folch et al. (1957). The total lipids were measured gravimetrically after solvent evaporation under $\mathrm{N}_{2}$ stream. Hepatic fat-free mass was estimated as the difference between the hepatic weight and the fat content.

The lipid extract was dissolved in isopropanol. Total cholesterol was quantified by an enzymatic method (Roschlau et al. 1974), free cholesterol was analysed by the same method, but lacking esterase enzyme, and esterified cholesterol was estimated as the difference between the total and the free cholesterol. Phospholipids were measured by the colorimetric method of Baginsky et al. (1967), and triacylglycerol was measured enzymatically by using a commercial kit (Triglyceride GPO-PAP, Boehringer Mannheim $\mathrm{GmbH}$ ).

\section{3-Hydroxy-3-methylgutaryl-CoA reductase activity}

The enzyme 3-hydroxy-3-methylglutaryl (HMG)-CoA reductase was isolated from hepatic microsomes following the method number one described in the paper of Kleinsek et al. (1981). The enzyme activity in solubilized fractions was assayed spectrophotometrically at $340 \mathrm{~nm}$ by measuring the rate of $\mathrm{NADP}^{+}$release (Kleinsek et al. 1981). The results were expressed as nmol $\mathrm{NADP}^{+} /$min per mg protein.

\section{Faecal analyses}

Neutral and acid faecal steroids were extracted by the method described by Kalek et al. (1984). Cholesterol in the neutral fraction was quantified by an enzymatic method (Roschlau et al. 1974), and bile acids in the acid fraction were measured by the hydroxysteroid dehydrogenase method described by Talalay (1960) as modified by Turley \& Dietschy (1978).

\section{Statistical analysis}

Values are presented as means with their standard errors. ANOVA tests were used to test the significance of differences $(P<0.05)$ among groups with subsequent Duncan's $t$ test for mean comparisons.

\section{Results \\ Food intake and final body weight}

Food intake was significantly lower in groups HC, HS and HI than in group C. However, energy intakes as well as final body weights were lower in the rats fed on both legume diets than in rats fed on casein diets (Table 3).

\section{Serum lipids levels}

Table 4 shows the effects of the different diets on triacylglycerol and cholesterol contents in serum. The rats fed on the $\mathrm{HC}$ and $\mathrm{HI}$ diets showed similar values of serum triacylglycerol as the reference-control rats $(\mathrm{C})$. In contrast, when faba bean seeds were used as source of protein (diet HS) the rats showed a significantly lower triacylglycerol level.

Serum total cholesterol concentration was significantly lower in the rats fed on the HS and HI diets than in those fed on the HC diet. Despite the hypocholesterolaemic effect

Table 3. Body weights, and food and energy intakes of rats fed on the experimental diets for 2 weeks* (Mean values with standard errors of means for ten rats per group)

\begin{tabular}{|c|c|c|c|c|c|c|c|c|}
\hline \multirow[t]{2}{*}{ Experimental groups ... } & \multicolumn{2}{|c|}{ C } & \multicolumn{2}{|c|}{$\mathrm{HC}$} & \multicolumn{2}{|c|}{ HS } & \multicolumn{2}{|c|}{$\mathrm{HI}$} \\
\hline & Mean & $\overline{\text { SEM }}$ & Mean & $\overline{\text { SEM }}$ & Mean & $\overline{\text { SEM }}$ & Mean & $\overline{\text { SEM }}$ \\
\hline $\begin{array}{l}\text { Initial body weight }(\mathrm{g}) \\
\text { Final body weight }(\mathrm{g}) \\
\text { Food intake }(\mathrm{g} / \mathrm{d}) \\
\text { Energy intake }(\mathrm{kJ} / \mathrm{d})\end{array}$ & $\begin{array}{c}276^{\mathrm{a}} \\
315^{\mathrm{a}} \\
19 \cdot 5^{\mathrm{a}} \\
306^{\mathrm{a}}\end{array}$ & $\begin{array}{l}4 \\
6 \\
0 \cdot 5 \\
8\end{array}$ & $\begin{array}{c}276^{\mathrm{a}} \\
317^{\mathrm{a}} \\
14 \cdot 4^{\mathrm{b}} \\
294^{\mathrm{a}}\end{array}$ & $\begin{array}{l}3 \\
5 \\
0 \cdot 2 \\
5\end{array}$ & $\begin{array}{c}279^{\mathrm{a}} \\
303^{\mathrm{b}} \\
14 \cdot 5^{\mathrm{b}} \\
261^{\mathrm{b}}\end{array}$ & $\begin{array}{l}6 \\
6 \\
0 \cdot 4 \\
7\end{array}$ & $\begin{array}{l}279^{\mathrm{a}} \\
299^{\mathrm{b}} \\
13 \cdot 3^{\mathrm{c}} \\
271^{\mathrm{b}}\end{array}$ & $\begin{array}{l}4 \\
5 \\
0 \cdot 2 \\
4\end{array}$ \\
\hline
\end{tabular}

$\mathrm{C}$, rats fed on control diet; $\mathrm{HC}$, rats fed on hypercholesterolaemic diet with casein; HS, rats fed on hypercholesterolaemic diet with Vicia faba seeds; HI, rats fed on hypercholesterolaemic diet with Vicia faba protein isolate.

a,b,c Mean values within a row with unlike superscript letters were significantly different $(P<0.05)$.

${ }^{*}$ For details of diets and procedures, see Tables 1 and 2 and p. 608. 
Table 4. Serum lipid levels and atherogenic index of rats fed on the experimental diets for 2 weeks (Mean values with standard errors of means for ten rats per group)

\begin{tabular}{|c|c|c|c|c|c|c|c|c|}
\hline \multirow[t]{2}{*}{ Experimental groups... } & \multicolumn{2}{|c|}{$\mathrm{C}$} & \multicolumn{2}{|c|}{$\mathrm{HC}$} & \multicolumn{2}{|c|}{ HS } & \multicolumn{2}{|c|}{$\mathrm{HI}$} \\
\hline & Mean & $\overline{\text { SEM }}$ & Mean & SEM & Mean & SEM & Mean & SEM \\
\hline Triacylglycerol (mmol/l) & $1 \cdot 21^{\mathrm{a}}$ & 0.19 & $1 \cdot 20^{\mathrm{a}}$ & $0 \cdot 19$ & $0.73^{b}$ & 0.13 & $1.07^{\mathrm{ab}}$ & 0.10 \\
\hline Total cholesterol $(\mathrm{mmol} / \mathrm{l})$ & $1 \cdot 24^{\mathrm{C}}$ & 0.11 & $3.48^{\mathrm{a}}$ & 0.29 & $2 \cdot 20^{\mathrm{b}}$ & 0.16 & $2.44^{\mathrm{b}}$ & 0.23 \\
\hline HDL-cholesterol (mmol/l) & $0.85^{a}$ & 0.12 & $0.92^{\mathrm{a}}$ & 0.12 & $0.95^{\mathrm{a}}$ & 0.06 & $0.83^{\mathrm{a}}$ & 0.09 \\
\hline (LDL+VLDL)-cholesterol (mmol/l) & $0.39^{d}$ & 0.08 & $2.54^{\mathrm{a}}$ & 0.35 & $1 \cdot 11^{\mathrm{c}}$ & 0.08 & $1 \cdot 61^{\mathrm{b}}$ & 0.19 \\
\hline Atherogenic index† & $0.41^{d}$ & 0.07 & $3.07^{\mathrm{a}}$ & 0.47 & $1.22^{\mathrm{C}}$ & 0.13 & $1.79^{\mathrm{b}}$ & 0.19 \\
\hline
\end{tabular}

C, rats fed on control diet; HC, rats fed on hypercholesterolaemic diet with casein; HS, rats fed on hypercholesterolaemic diet with Vicia faba seeds; HI, rats fed on hypercholesterolaemic diet with Vicia faba protein isolate.

a,b,c,d Mean values within a row with unlike superscript letters were significantly different $(P<0.05)$

* For details of diets and produces, see Tables 1 and 2 and p. 608.

† Defined as (VLDL+LDL)-cholesterol:HDL-cholesterol ratio.

of faba beans, the rats in groups HS and HI showed higher cholesterol levels than reference-control rats $(\mathrm{C})$. These dietary modifications were specific for (LDL+VLDL)cholesterol because no significant differences in HDLcholesterol concentration were found among the four experimental groups. Feeding faba bean resulted in significantly lower atherogenic index values $(P<0 \cdot 05)$.

\section{Liver weights and hepatic composition}

The inclusion of faba bean seeds in the high-fat hypercholesterolaemic diet induced a significant decrease in liver weight as compared with the casein-based high-fat hypercholesterolaemic diet. Mean liver weight in the $\mathrm{HI}$ group was between those of the HC and HS groups. When data were adjusted per body weight no significant differences were found among HC, HS and HI groups.

The three high-fat hypercholesterolaemic diets led to a significant increase $(P<0.05)$ in liver weight as compared with reference-controls $(C)$, which was due to an increase in both fat mass and fat-free mass. Concerning fat mass, the three measured components: total cholesterol, phospholipids and triacylglycerol, were significantly increased $(P<0.05$; Table 5).

By comparing the liver composition in the groups $\mathrm{HC}$, HS and HI it was observed that the amount of liver fat was significantly lower when rats were fed on legume-based diets (HS and $\mathrm{HI}$ ). In contrast, no significant differences were found in fat-free mass, indicating that the faba bean diets did not produce malnutrition. Consequently, the fat mass:fat-free mass ratio was significantly lower in those groups than in the group $\mathrm{HC}(P<0.05)$.

Total cholesterol content was significantly lower in rats fed on the HS and HI diets than in rats fed on the $\mathrm{HC}$ diet $(P<0 \cdot 05)$. The lowest value was observed for the group HS. The decreased cholesterol content present in this group, compared with the $\mathrm{HC}$ group, was due to a reduction in both free and esterified pools; in contrast, in the group HI only free cholesterol was reduced.

The groups HC and HI had similar phospholipid contents. In both cases, the values were significantly lower than those of the group HS $(P<0 \cdot 05)$. Finally, faba bean feeding (HS and $\mathrm{HI}$ ) induced a reduction in triacylglycerol content as compared with casein (HC). No significant differences were found between the groups fed on the whole seeds or the protein isolate.

\section{Faecal lipid excretion}

When compared with the group C, the HC, HS and HI fed rats showed an increased faecal lipid excretion. This

Table 5. Liver weight and hepatic composition of rats fed on the experimental diets for 2 weeks*

(Mean values with standard errors of means for ten rats per group)

\begin{tabular}{|c|c|c|c|c|c|c|c|c|}
\hline \multirow[t]{2}{*}{ Experimental groups... } & \multicolumn{2}{|c|}{ C } & \multicolumn{2}{|c|}{$\mathrm{HC}$} & \multicolumn{2}{|c|}{$\mathrm{HS}$} & \multicolumn{2}{|c|}{$\mathrm{HI}$} \\
\hline & Mean & $\overline{\text { SEM }}$ & Mean & $\overline{\text { SEM }}$ & Mean & $\overline{\text { SEM }}$ & Mean & $\overline{\text { SEM }}$ \\
\hline Weight (g) & $8 \cdot 10^{c}$ & 0.21 & $14 \cdot 78^{a}$ & 0.47 & $13 \cdot 05^{b}$ & 0.63 & $13.53^{\mathrm{ab}}$ & 0.78 \\
\hline (\% body weight) & $2 \cdot 44^{\mathrm{b}}$ & 0.03 & $4 \cdot 61^{a}$ & 0.15 & $4 \cdot 27^{a}$ & 0.18 & $4 \cdot 50^{\mathrm{a}}$ & 0.20 \\
\hline \multicolumn{9}{|l|}{ Cholesterol $(\mathrm{mg} / \mathrm{g})$} \\
\hline Total & $4 \cdot 9^{d}$ & $0 \cdot 1$ & $12 \cdot 4^{\mathrm{a}}$ & 0.5 & $9 \cdot 0^{\mathrm{C}}$ & 0.5 & $11 \cdot 5^{\mathrm{b}}$ & 0.7 \\
\hline Free & $3 \cdot 8^{\mathrm{c}}$ & 0.1 & $6 \cdot 2^{a}$ & 0.5 & $4 \cdot 4^{\mathrm{b}}$ & 0.3 & $4 \cdot 6^{\mathrm{b}}$ & 0.4 \\
\hline Esterified & $1 \cdot 1^{\mathrm{c}}$ & 0.1 & $6 \cdot 0^{a}$ & 0.3 & $5 \cdot 0^{\mathrm{b}}$ & 0.3 & $6 \cdot 4^{\mathrm{a}}$ & 0.3 \\
\hline Phospholipids (mg/g) & $16 \cdot 0^{c}$ & 0.4 & $21 \cdot 1^{b}$ & 0.9 & $28 \cdot 0^{\mathrm{a}}$ & 1.1 & $21 \cdot 0^{\mathrm{b}}$ & 1.6 \\
\hline Triacylglycerol $(\mathrm{mg} / \mathrm{g})$ & $15 \cdot 6^{\mathrm{c}}$ & 0.4 & $49 \cdot 3^{a}$ & $2 \cdot 8$ & $36 \cdot 7^{b}$ & 2.5 & $36 \cdot 1^{\mathrm{b}}$ & 2.6 \\
\hline Fat mass (g/liver) & $0.30^{c}$ & 0.01 & $1.23^{\mathrm{a}}$ & 0.06 & $0.93^{b}$ & 0.05 & $0.93^{b}$ & 0.07 \\
\hline Fat-free mass (g/liver) & $7 \cdot 81^{\mathrm{b}}$ & 0.25 & $13.56^{\mathrm{a}}$ & 0.43 & $12 \cdot 68^{a}$ & 0.51 & $12 \cdot 66^{a}$ & 1.03 \\
\hline Fat mass:fat-free mass $(\mathrm{g} / \mathrm{g} \times 100)$ & $3 \cdot 8^{\mathrm{c}}$ & 0.2 & $9 \cdot 0^{\mathrm{a}}$ & 0.4 & $7 \cdot 3^{\mathrm{b}}$ & 0.5 & $7 \cdot 3^{\mathrm{b}}$ & 0.6 \\
\hline
\end{tabular}

$\mathrm{C}$, rats fed on control diet; HC, rats fed on hypercholesterolaemic diet with casein; HS, rats fed on hypercholesterolaemic diet with Vicia faba seeds; HI, rats fed on hypercholesterolaemic diet with Vicia faba protein isolate.

a,b,c,d Mean values within a row with unlike superscript letters were significantly different $(P<0.05)$.

${ }^{*}$ For details of diets and procedures, see Tables 1 and 2 and p. 608. 
Table 6. Faecal excretion of total fat, cholesterol and bile acids in rats fed on the experimental diets for 2 weeks*

(Mean values with standard errors of means for ten rats per group)

\begin{tabular}{|c|c|c|c|c|c|c|c|c|}
\hline \multirow[t]{2}{*}{ Experimental groups ... } & \multicolumn{2}{|c|}{$\mathrm{C}$} & \multicolumn{2}{|c|}{$\mathrm{HC}$} & \multicolumn{2}{|c|}{ HS } & \multicolumn{2}{|c|}{$\mathrm{HI}$} \\
\hline & Mean & SEM & Mean & SEM & Mean & SEM & Mean & SEM \\
\hline $\begin{array}{l}\text { Dry faecal weight }(\mathrm{g} / \mathrm{d}) \\
\text { Total fat }(\mathrm{mg} / \mathrm{d}) \\
\text { Cholesterol }(\mu \mathrm{mol} / \mathrm{d}) \\
\text { Bile acids }(\mu \mathrm{mol} / \mathrm{d})\end{array}$ & $\begin{array}{l}2 \cdot 16^{b} \\
142^{c} \\
10 \cdot 4^{d} \\
20 \cdot 2^{c}\end{array}$ & $\begin{array}{l}0.09 \\
9 \\
0.5 \\
1.2\end{array}$ & $\begin{array}{l}0 \cdot 91^{\mathrm{d}} \\
353^{\mathrm{b}} \\
43 \cdot 8^{\mathrm{c}} \\
82 \cdot 9^{\mathrm{b}}\end{array}$ & $\begin{array}{l}0.04 \\
21 \\
2 \cdot 2 \\
9.4\end{array}$ & $\begin{array}{l}\quad 4 \cdot 22^{\mathrm{a}} \\
759^{\mathrm{a}} \\
234 \cdot 4^{\mathrm{a}} \\
109 \cdot 2^{\mathrm{a}}\end{array}$ & $\begin{array}{c}0.25 \\
76 \\
8.7 \\
14.3\end{array}$ & $\begin{array}{c}1 \cdot 16^{\mathrm{c}} \\
421^{\mathrm{b}} \\
80 \cdot 9^{\mathrm{b}} \\
81 \cdot 9^{\mathrm{b}}\end{array}$ & $\begin{array}{c}0.08 \\
28 \\
5 \cdot 4 \\
4.4\end{array}$ \\
\hline
\end{tabular}

$\mathrm{C}$, rats fed on control diet; HC, rats fed on hypercholesterolaemic diet with casein; HS, rats fed on hypercholesterolaemic diet with Vicia faba seeds; HI, rats fed on hypercholesterolaemic diet with Vicia faba protein isolate.

a,b,c,d Mean values within a row with unlike superscript letters were significantly different $(P<0.05)$

* For details of diets and procedures, see Tables 1 and 2 and p. 608.

increase was greater in the HS group when compared with $\mathrm{HC}$ and $\mathrm{HI}$ groups $(P<0 \cdot 001)$ (Table 6).

Giving faba bean seeds in the high-fat hypercholesterolaemic diet instead of casein produced a marked increase in cholesterol excretion. This effect was maintained when faba bean was added as protein isolate, although in this case the amount of cholesterol excreted was lower than that of the group HS. A significant increase $(P<0.05)$ in bile acid excretion was also observed with faba bean seeds but not with protein isolate.

\section{3-Hydroxy-3-methylglutaryl-CoA reductase activity}

Liver HMG-CoA reductase activity was significantly decreased by the three high-fat hypercholesterolaemic diets as compared with the controls $(P<0.05)$. When comparing these diets we observed that the group HS presented a significantly higher enzyme activity than the groups $\mathrm{HC}$ and $\mathrm{HI}(P<0 \cdot 05$; Fig. 1$)$.

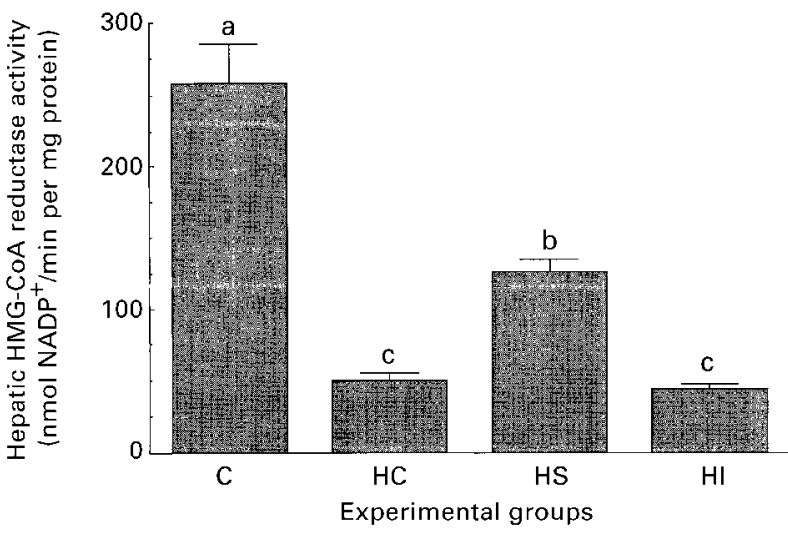

Fig. 1. Hepatic 3-hydroxy-3-methylglutaryl (HMG)-CoA reductase activity in rats (ten per group) fed on the experimental diets for 2 weeks. For details of diets and procedures, see Tables 1 and 2 and p. 608. Values are means with the standard errors of the means, shown by vertical bars. ${ }^{a, b, c}$ Mean values with unlike superscript letters were significantly different $(P<0.05)$. $\mathrm{C}$, rats fed on control diet; $\mathrm{HC}$, rats fed on hypercholesterolaemic diet with casein; $\mathrm{HS}$, rats fed on hypercholesterolaemic diet with Vicia faba seeds; HI, rats fed on hypercholesterolaemic diet with Vicia faba protein isolate.

\section{Discussion}

The hypocholesterolaemic effect of soyabean seeds and its proteins is well documented (Potter, 1995). However, the efficacy of other legumes on cholesterol metabolism has not been adequately demonstrated. The present work focused on the hypocholesterolaemic effects of faba bean, a legume commonly consumed in some European countries, particularly in the Mediterranean area.

Under our experimental conditions, body weights were lower in rats fed on faba bean-based diets than in rats fed on casein-based diets, probably because of the different energy intakes. Although no significant differences were found among $\mathrm{HC}$, HS and $\mathrm{HI}$ groups when liver weights were adjusted per body weight, liver size was significantly enhanced by the intake of all hypercholesterolaemic diets as compared with the reference-control group (C), due to an increase in both fat mass and fat-free mass. The increase induced by the inclusion of Vicia faba in the diet was lower than that induced by the $\mathrm{HC}$ diet, due to minor fat accumulation.

Faba diets (HS and HI) showed a hypocholesterolaemic effect as compared with the HC casein diet (Table 4). Nevertheless, the rats in these groups remained hypercholesterolaemic because they showed significantly higher plasma levels than reference-control rats (C). The effects of the legume on (LDL+VLDL)-cholesterol were responsible for the hypocholesterolaemic effect, because no significant differences were found in HDL-cholesterol. These results are in good accordance with several published reports where the hypocholesterolaemic properties of other legume seeds and legume proteins were demonstrated (Marfo et al. 1990; Lasekan et al. 1995; Dabai et al. 1996).

The effect of legume proteins has been attributed to their amino acid profile (Nagata et al. 1982; Dabai et al. 1996) which leads to limited number of LDL particles being available for the transport of cholesterol in the plasma (Kingman et al. 1993). Thus, a high lysine:arginine ratio induces hypercholesterolaemia (Kritchevsky et al. 1982), as do a high methionine content and a high methionine: glycine ratio (Tanaka \& Sugano, 1989). In this context it is important to point out that the lysine:arginine ratios for casein, faba bean seeds and protein isolate obtained in previous studies from our laboratory were $0.96,0.33$ and $0 \cdot 26$ respectively, the methionine content for casein, faba bean seeds and protein isolate were 19,5 and $7 \mathrm{mg} / \mathrm{g}$ 
protein respectively, and the methionine:glycine ratios were $0.85,0.17$ and 0.29 for casein, faba bean seeds and protein isolate respectively (Fernández-Quintela et al. 1997, 1998). These data can help to explain the hypocholesterolaemic effect induced by the HS and HI diets. The HS diet produced a stronger decrease in (LDL+VLDL)-cholesterol than the HI diet $(P<0.05)$, because the reduction in cholesterol absorption induced by the fibre contained in the whole seeds is added to that of the components in the isolate (Amigo et al. 1992; Potter, 1995). In addition, the fructose component of the saccharose present in the HI diet may have contributed to the observed differences between $\mathrm{HI}$ and HS groups (Roche, 1999).

The effects of faba bean on cholesterol metabolism were also observed in the liver. Thus, liver total cholesterol was significantly lower in rats fed on faba bean than in rats fed on casein (HC) $(P<0.05$; Table 5$)$. This reduction, as well as the decrease in plasma cholesterol, was more marked in the group fed on whole seeds than in the group fed on the protein isolate $(P<0.05)$. In addition, in this case the effect of the fibre and other non-protein components of the seeds as well as the fructose component of the saccharose present in the HI diet can account for differences in liver total cholesterol between HS and HI groups.

Since cholesterol is eliminated from the body primarily via the hepatobiliary system itself or as bile acids, an increased cholesterol output from the liver via bile in the groups HS and HI could be suggested. Thus, in the liver of the rats fed on faba bean, cholesterol would be removed via bile rather than secreted into the circulation. In order to test this hypothesis, cholesterol and bile acids were determined in faeces (Table 6). Feeding the faba bean-protein diet (HI) resulted in an increased cholesterol excretion in faeces as compared with the HC diet, but the excretion of bile acids was not changed. This fact may indicate that the increase in faecal cholesterol excretion was solely due to an enhanced biliary cholesterol excretion and not to a reduction in cholesterol absorption. Some authors have reported that soyabean protein may be less digestible than casein and that the undigested protein could bind bile acids, facilitating their excretion and preventing their absorption (Tersptra et al. 1994). The discrepancy with the study from Terpstra et al. (1994) could be due to the fact that we did not observe any difference in digestibility between casein and isolated faba bean proteins in a previous study (FernándezQuintela et al. 1998).

The intact faba bean diet (HS) induced an increase in both cholesterol and bile acid faecal excretion, suggesting the involvement of an increase in biliary cholesterol secretion and a reduction in sterol absorption due, at least in part, to fibre. The higher biliary cholesterol excretion observed in HS group as compared with HI group can be explained by the saponin content of the seeds (Rigotti et al. 1989).

Since HMG-CoA reductase is a key enzyme in the synthesis of cholesterol, the activity of this enzyme was assessed in the liver of the rats in order to determine if changes in cholesterol synthesis were also involved in the hypocholesterolaemic effect of faba bean. The data obtained in the present study (Fig. 1) suggest that this effect cannot be explained by a reduction in the activity of this enzyme. The HI group did not present significant differences from the $\mathrm{HC}$ group, and the HS group showed a significantly increased activity as compared with the $\mathrm{HC}$ group, probably due to the proposed reduction in cholesterol and bile acids absorption, and to the lower hepatic cholesterol content. The decreased enzyme activity observed in the groups $\mathrm{HC}$, HS and HI as compared with the reference-control group (C) can be explained by the high cholesterol intake, because it has been demonstrated that this situation leads to the accumulation of cholesterol in liver which inhibits the HMG-CoA reductase activity (Brown \& Goldstein, 1986).

It is important to consider the distribution of liver total cholesterol in two pools, free and esterified, because it has been demonstrated that free cholesterol down-regulates LDL-cholesterol receptors (Daumiere et al. 1992). Thus, the reduced free cholesterol pool showed by the rats fed on faba bean (HS and HI) in comparison with those fed on casein $(\mathrm{HC})$ could be mediating, at least in part, the reduced plasma (LDL+VLDL)-cholesterol concentrations observed in these rats.

On the other hand, it is interesting to emphasize the reduced liver triacylglycerol content in the rats fed on the faba bean as compared with those fed on casein (HC) (Table 5). This reduction contributes to a decreased liver weight in these rats. It has been demonstrated that dietary fibre significantly increases faecal fat excretion by reducing the efficiency of fat digestion and by inhibiting the pancreatic lipase activity (Lairon, 1996). Other authors have proposed that the reduced liver triacylglycerol content may be due to a reduction in lipogenesis induced by legume protein (Nagata et al. 1982; Iritani et al. 1986). Hepatic phospholipids were significantly increased in the group HS. This could be related to an increased biliary phospholipid output due to saponins, as suggested by Rigotti et al. (1989).

Feeding rats high-fat hypercholesterolaemic diets did not induce hypertriacylglycerolaemia (Table 4), as in other studies (Zulet et al. 1999a). Surprisingly, when faba bean seeds were used as source of protein, plasma triacylglycerol levels were significantly reduced and remained lower than those of reference-control rats $(C)$. This fact may be related in part to the lower final body weight reached by rats in the HS group compared with rats fed the control casein diet. Higher body weights are usually accompanied by higher serum triacylglycerol levels. Since the inclusion of a faba bean-protein isolate in the diet did not lead to a significant decrease in plasma triacylglycerol as compared with the reference-control rats $(\mathrm{C})$, it may be suggested that the change induced by faba bean-seed diet is attributable to its small content of saccharose and to the non-protein components, like fibre, which are present in the seeds and eliminated during the isolate obtention process. In this context, it has been described previously that fibre can reduce the absorption of dietary fat (Lairon, 1996). This hypothesis is supported by the fact that despite having a similar fat intake, rats fed on faba bean seeds excreted a significantly higher amount of fat than rats fed on casein (HC) (Table 6). Nevertheless, it may be supposed that this 
is not the only explanation, because if it were so, triacylglycerol levels in the HS group would not be lower than that of the reference-control rats $(\mathrm{C})$ fed on a standardfat diet. A potential explanation could be the greater amount of simple sugars in the HC diet than in the HS diet (Roche, 1999).

Taking all these results into account, it can be concluded that the faba bean protein-isolate obtained by using the method previously described was useful to improve the metabolic alterations induced by feeding a hypercholesterolaemic diet compared with casein. Nevertheless, the effectiveness of this isolate is lower than that of the whole seeds probably because various components present in the intact bean (fibre, saponins, flavonoids, tripsin inhibitors, phytosterols, etc) can be acting and their effects are added. The influence of the fructose component of the saccharose present in the HI diet should not be disregarded when comparing HS with HI diets. The hypocholesterolaemic effect of faba bean proteins is the result, at least in part, of an increased faecal cholesterol excretion, whereas in the case of whole seeds a reduced steroid absorption is added to this mechanism.

\section{Acknowledgements}

This study was supported by a grant from the Government of the País Vasco (Cooperation Euskadi-Navarra-Aquitania Programme) and a grant from the University of the País Vasco (UPV 101.123-EA140/94).

\section{References}

Amigo L, Marzolo MP, Aguilera JM, Hohlberg A, Cortés M \& Nervi F (1992) Influence of different dietary constituents of beans (Phaseolus vulgaris) on serum and biliary lipids in the rat. Journal of Nutrition and Biochemistry 3, 486-490.

Association of Official Analytical Chemists (1997) Official Methods of Analysis of AOAC International, 16th ed [P Cunniff, editor]. Gaithersburg, FL: AOAC International.

Baginsky ES, Fos PP \& Zack B (1967) Microdetermination of inorganic phosphate, phospholipids and total phosphate in biological material. Clinical Chemistry 13, 326-332.

Brown MS \& Goldstein JL (1986) Multivalent feedback regulation of HMG-CoA-reductase, a control mechanism coordinating isoprenoid synthesis and cell growth. Journal of Lipid Research 21, 505-517.

Dabai FD, Walker AF, Sambrook IE, Welch VA, Owen RW \& Abeyasekera S (1996) Comparative effects on blood lipids and faecal steroids of five legume species incorporated into a semipurified hypercholesterolaemic rat diet. British Journal of Nutrition 75, 557-571.

Daumiere CM, Woollett LA \& Dietschy JM (1992) Fatty acids regulate hepatic low density lipoprotein receptor activity through redistribution of intracellular cholesterol pools. Proceedings of the National Academy of Sciences of the United States of America 89, 10797-10801.

Duane WC (1997) Effects of legume consumption on serum cholesterol, biliary lipids, and sterol metabolism in humans. Journal of Nutrition Research 38, 1120-1128.

Dwyer J (1995) Overview: dietary approaches for reducing cardiovascular disease risks. Journal of Nutrition 125, 656-665.

Fernández-Quintela A, Del Barrio AS, Macarulla MT \& Martínez JA (1998) Nutritional evaluation and metabolic effects in rats of protein isolates obtained from seeds of three legume species. Journal of Science of Food and Agriculture 78, 251-260.

Fernández-Quintela A, Macarulla MT, Del Barrio AS \& Martínez JA (1997) Composition and functional properties of protein isolates obtained from commercial legumes grown in northern Spain. Plant Foods for Human Nutrition 51, 331-342.

Folch J, Lees M \& Sloane Stanley GH (1957) A simple method for the isolation and purification of total lipides from animal tissues. Journal of Biological Chemistry 226, 497-509.

Forsythe WA (1986) Comparison of dietary casein or soy protein effects on plasma lipids and hormone concentrations in the gerbil (Meriones unguiculatus). Journal of Nutrition 116, $1165-1171$.

Frühbeck G (1996a) Flavonoid intake and coronary mortality. Other antinutritional factors may also have a role. British Medical Journal 312, 1479.

Frühbeck G (1996b) Dietary fiber and coronary heart disease prevention. Journal of the American Medical Association 275, 1883.

Iritani N, Nagashima K, Fukuda H, Katsurada A \& Tanaka T (1986) Effects of dietary protein on lipogenic enzymes in rat liver. Journal of Nutrition 116, 190-197.

Kalek HD, Stellaard F, Kruis W \& Paumgartner G (1984) Detection of increased bile excretion by determination of bile acid content in single stool samples. Clinica Chimica Acta 140, 85-90.

Khosla P, Sammam S \& Carrol K (1991) Decreased receptor mediated LDL catabolism in casein-fed rabbits precedes the increase in plasma cholesterol levels. Journal of Nutritional Biochemistry 2, 203-209.

Kingman SM, Walker F, Low AG \& Sambrook IE (1993) Comparative effects of four legume species on plasma lipids and faecal steroid excretion in hypercholesterolaemic pigs. British Journal of Nutrition 69, 409-421.

Kleinsek A, Dugan RE, Baker TA \& Porter JW (1981) 3Hydroxy-3-methylglutaryl-CoA reductase from rat liver. Methods of Enzymology 71, 462-479.

Kritchevsky D, Tepper SA, Czarnecki SK \& Klurfeld DM (1982) Atherogenicity of animal and vegetable protein: influence of lysine to arginine ratio. Atherosclerosis 41, 429-431.

Lairon D (1996) Dietary fibres: effects on lipid metabolism and mechanisms of action. European Journal of Clinical Nutrition 50, $125-133$.

Lasekan JB, Cueth L \& Kham S (1995) Influence of dietary golden pea proteins versus casein on plasma and hepatic lipids in rats. Nutrition Research 15, 71-84.

Marfo EK, Wallace P, Timpo G \& Simpson BK (1990) Cholesterol lowering effect of jackbean (Canvalia ensiformis) seed protein. General Pharmacology 5, 753-757.

Nagata Y, Ishiwaki N \& Sugano M (1982) Studies on the mechanism of antihypercholesterolemic action of soy protein and soy protein-type amino acid mixtures in relation to the casein counterparts in rats. Journal of Nutrition 112, 16141625.

Otegui I, Fernández-Quintela A, De Diego A, Cid C, Macarulla MT \& Partearroyo MA (1997) Properties of spraydried and freeze-dried faba bean protein concentrates. International Journal of Food Science and Technology 32, 439-443.

Potter SM (1995) Overview of proposed mechanisms for the hypocholesterolemic effect of soy. Journal of Nutrition 125, 606S-611S.

Reeves PG, Nielsen FH \& Fahey GC Jr (1993) AIN-93 Purified diets for laboratory rodents: final report of the American Institute of Nutrition ad hoc writing committee on the reformation of the AIN-76A rodent diet. Journal of Nutrition 123, 1939-1951. 
Rigotti A, Marzolo MP, Ulloa N, González O \& Nervi F (1989) Effect of bean intake on biliary lipid secretion and on hepatic cholesterol metabolism in the rat. Journal of Lipid Research 30, 1041-1048.

Roche HM (1999) Dietary carbohydrates and triacylglycerol metabolism. Proceedings of the Nutrition Society 58, 201-207.

Roschlau P, Bernt E \& Gruber W (1974) Enzymatic determination of total cholesterol in serum. Zeitschrift für Klinische Chemie und Klinische Biochemie 12, 403-408.

Sharma RD (1987) An evaluation of hypocholesterolemic activity of some uncommon legumes. Nutrition Research 7, 351-363.

Talalay P (1960) Enzyme analysis of steroid hormones. Methods of Biochemistry Analitical 8, 119-143.

Tanaka K \& Sugano M (1989) Effects of addition of sulfurcontaining amino acids and glycine to soyabean protein and casein on serum cholesterol levels of rats. Journal of Nutritional Science and Vitaminology 35, 323-332.

Terpstra AHM, Laitinen L, Stucchi AF \& Nicolosi RJ (1994) The effect of semipurified diets containing two levels $(20 \%$ and $40 \%$ ) of either casein or soyabean protein isolate and concentrate on plasma lipids in hamsters. Nutrition Research 14, 885-895.
Thompson LU (1977) Preparation and evaluation of mung bean protein isolates. Journal of Food Science 42, 202-206.

Turley SD \& Dietschy JM (1978) Re-evaluation of the $3 \alpha-$ hydroxysteroid dehydrogenase assay for total bile acids in bile. Journal of Lipid Research 19, 924-928.

Warnick GR, Benderson J \& Albers JJ (1982) Dextran sulfate$\mathrm{Mg}^{2+}$ precipitation procedure for quantitation of high-lipoprotein cholesterol. Clinical Chemistry 28, 1379-1388.

Zulet MA \& Martínez JA (1995) Corrective role of chickpea intake on a dietary-induced model of hypercholesterolemia. Plant Foods for Human Nutrition 48, 269-277.

Zulet MA, Barber A, Garcin H, Higueret P \& Martínez JA (1999a) Alterations in carbohydrate and lipid metabolism induced by a diet rich in coconut oil and cholesterol in rat model. Journal of the American College of Nutrition 18, 36-42.

Zulet MA, Macarulla MT, Portillo MP, Nöel-Suberville C, Higueret P \& Martínez JA (1999b) Lipid and glucose utilization in hypercholesterolemic rats fed a diet containing heated chickpea (Cicer aretinum L.): a potential functional food. International Journal of Vitaminology and Nutrition Research 69, 403-411. 